BULLETIN OF PNRPU. GEOLOGY. OIL \& GAS ENGINEERING \& MINING

ВЕСТНИК ПНИПУ. ГЕОЛОГИЯ. НЕФТЕГАЗОВОЕ И ГОРНОЕ ДЕЛО

ISSN 2224-9923

Volume/ ToM 16 №1 2017

http://vestnik.pstu.ru/geo/

УДК 622.245 .44

Article / Статья

(C) PNRPU / ПНИПУ, 2017

\title{
SIMULATION OF WELL TEST PROCESSES WITH APPLICATION OF PACKERS
}

\section{N.E. Mikailova}

Azerbaijan State Oil and Industrial University (20 Azadlyg av., Baku, AZ1010, Republic of Azerbaijan)

\section{МОДЕЛИРОВАНИЕ ПРОЦЕССОВ ИСПЫТАНИЯ СКВАЖИН ПРИ ПРИМЕНЕНИИ ПАКЕРОВ}

\section{Н.Э. Микаилова}

Азербайджанский государственный университет нефти и промышленности (AZ1010, Азербайджан, г. Баку, Азадлыг пр., 20)

Received / Получена: 17.11.2016. Accepted / Принята: 07.03.2017. Published / Опубликована: 31.03.2017

\section{Key words:}

well test, packer, formation, inflow, reservoir pressure, flow resistance, bottom hole area, interpacker space, pressure buildup curves, after-inflow effect, permeability of bottom hole area of formation, productivity index, potential rate, contamination, drilling process.
Ключевые слова: испытания скважин, пакер, пласт, приток, пластовое давление, сопротивление потока, призабойная зона, межпакерное пространство, кривые восстановления давления, послеприточный эффект, проницаемость призабойной зоны пласта, коэффициент продуктивности, потенциальный дебит, загрязнение, процесс бурения.
The paper considers simulation of well test processes with application of packers. Based on well parameters at different times (before a well is closed and the point in time under consideration) a mathematical model is compiled. Superposition principles are used for constructing points of pressure recovery curve.

Based on that, four cases of using packers are considered according to actual pressure diagrams.

Processing of build-up curves helps to determine other characteristics of a formation as well. Since a bottom hole zone is broken in a number of cases and its permeability is reduced, an amount of reservoir contamination indicators is defined as an additional pressure drawdown that has to be created to overcome resistance of reduced permeability zone.

It should be noted that existing works related to assessment of influence of after-inflow effect relate to either determination of its duration or adjustment of pressure build up curves by introducing correction factors.

To overcome a challenge of pressure build-up taking into account an effect of pressure drop and after-inflow effect an approximate method to solve problems of nonstationary flow is used. The method of integral relations allows obtaining solutions in a simple analytical form.

After a well is closed, conditions for redistribution of pressure in bottom hole area are changing. At remote sections of a formation the process continues to flow without changing as during the functioning of a well. Therefore, it is supposed that pressure wave continues to propagate according to the Says-Horner law.

As it was determined during modeling of various penetration conditions, pressure distribution curves in bottom hole area have clear straight horizontal sections after well closure. The length of sections increases with the increase of bottom hole pressure.

If the cause and nature of build-up curves are known full information about pressure change after well shut will be used. So, it will help to determine parameters of distant and bottom hole area of reservoir more accurately.

Рассмотрено моделирование процессов испытания скважин при применении пакеров. С этой целью на основе параметров скважины в разные периоды (до закрытия и в рассматриваемый момент времени) составлена математическая модель. При этом использованы принципы суперпозиции для построения точек кривой восстановления давления.

На основе этого рассмотрено четыре варианта применения пакеров по фактическим диаграммам давления.

С помощью обработки кривых восстановления давления (КВД) можно определить и другие характеристики пласта. Так как при вскрытии пласта его призабойная зона в ряде случаев нарушается и ее проницаемость оказывается сниженной, количество показателей загрязнения пласта определяется как дополнительный перепад давления, который следует создать, чтобы преодолеть сопротивление зоны пониженной проницаемости.

Следует отметить, что существующие работы, связанные с оценкой влияния послеприточного эффекта, касаются либо определения длительности его действия, либо корректировки КВД введением поправочных коэффициентов.

Для решения задачи о восстановлении давления с учетом влияния эффекта снижения давления и послеприточного эффекта воспользуемся приближенным методом решения задач нестационарной фильтрации - методом интегральных соотношений, который позволяет получить решения в простой аналитической форме.

После закрытия скважины изменятся условия перераспределения давления в призабойной зоне. На удаленных участках пласта процесс продолжает протекать, не изменяясь, как и при функционировании скважины. Поэтому считаем, что волна давления продолжает распространяться по закону Сейза-Хорнера.

В прискважинной зоне, как было установлено при моделировании различных условий фильтрации, кривые распределения давления после закрытия скважины характеризуются выраженными прямолинейными горизонтальными участками, протяженность которых растет с ростом забойного давления.

Знание причины и характера искривления КВД позволит использовать при интерпретации всю информацию об изменении давления после закрытия скважины, а следовательно, точнее определить характеристики удаленной и призабойной зон пласта.

Nigiar E. Mikailova - PhD student at the Oil and Gas Engineering Department (mob. tel.: +994 5036649 41, e-mail: mikailova_nigar@mail.ru).

Микаилова Нигяр Энвер кызы - диссертант кафедры нефтегазовой инженерии (моб. тел.: +994 50366 49 41, e-mail: mikailova_nigar@mail.ru). 


\section{Introduction}

Buil-up curve analysis is the most widly used method in drilling well test. Shut-in of well being on steady production is considered as a result of continuing production with the same rate of production and injection, that start after well shutin and continue during shut-in period with the same production rate [1].

Such formulation of the problem provides to describe pressure change in shut-in well using the same equation, where production and injection rates are characterized by $+q$ and $-q$.

\section{Selection of criteria to model pressure buil-up curves}

Difference between initial reservoir pressure $p_{\text {res }}$ and bottome hole pressure of shut-in well $p_{\mathrm{w}}$ can be represented as a sum of pressure drawdown caused by production of a well with rate $+q$ during the time $(T+\theta)$ and rate $-q$ during $\theta$, where $T$ is time of well performance before actual well shutin; $\theta$ is time of shut-in period before the time of interest [2].

Above mentioned can be written mathematically as

$$
\begin{aligned}
p_{\text {res }}-p_{\mathrm{w}} & =\frac{q \mu}{4 \pi R h} \ln \frac{2.25 R(T+\theta)}{m \mu \beta r_{\mathrm{w}}^{2}}+ \\
& +\frac{-q \mu}{4 \pi R h} \ln \frac{2.25 R \theta}{m \mu \beta r_{\mathrm{w}}^{2}}
\end{aligned}
$$

or

$$
\begin{gathered}
p_{\mathrm{w}}-p_{\text {res }}=\frac{q \mu}{4 \pi R h} \ln \frac{(T+\theta)}{\theta}= \\
=p_{\text {res }}-0.183 \frac{q \mu}{R h} \lg \frac{T+\theta}{\theta} .
\end{gathered}
$$

Such technique represents superposition principle.

Plotting of pressure build-up curve in coordinates $p_{\mathrm{w}}, \lg \frac{T+\theta}{\theta}$ according to (2) has to show a straight line. A point where a line crosses vertical axis correspons to $\lg \frac{T+\theta}{\theta}=0$, that equals to $0 \rightarrow \infty$, i.e. infinite shut-in period. As a result, it characterizes reservoir pressure. A line slope to horizontal axis according to (2) is determined as a combination of parameters $\frac{q \mu}{R h}$. If $M$ is a tangent of slope angle to horizontal axis then a mobility value can be determined as $\frac{R h}{\mu}=\frac{0.183 q}{M}$. Reservoir permeability could be determined having known viscosity of fluid in reservoir conditions and net reservoir thickness. A value of production rate must also be changed to bottomhole conditions through multiplying by the volume factor $B$.

Processing of pressure build-up curves can help to find other reservoir characteristics as well.

The number of reservoir contamination indicators is defined as an additional pressure drawdown that should be created to overcome resistance of a zone of low permeability [3-5]. An additional pressure drawdown is characterized by dimensionless number $\mathrm{S}$. Then pressure drawdown of low permeability is

$$
\Delta p_{\text {red }}=\Delta p_{S}=S \frac{q \mu}{2 \pi R h} .
$$

Bottomehole pressure of well being on production is determined as

$$
p_{\mathrm{w}}=p_{\text {res }}-\frac{q \mu}{4 \pi R h}\left[\ln \frac{2.25 R t}{m \mu \beta r_{\mathrm{w}}^{2}}+2 S\right] .
$$

If time when fluid inflow stopes is considerd $t=T$, then pressure $p_{\mathrm{w}}=p_{\text {res}}$, and $\mathrm{S}$ can be determined as

$$
S=\frac{p_{\text {res }}-p_{\text {ext.b }}}{2} \frac{4 \pi R h}{q \mu}-\frac{1}{2} \ln \frac{2.25 R T}{m \mu \beta r_{\mathrm{w}}^{2}} .
$$

If $p_{\text {res }}$ is found from the chart and angle coefficient $M$ is considered as $\frac{2.3 q \mu}{4 \pi R h}$, then previous ratio can be simplified to

$$
S=\frac{2.3}{2} \frac{p_{\text {res }}-p_{\text {ext.b }}}{M} \frac{4 \pi R h}{q \mu}-\frac{1}{2} \ln \frac{2.25 R T}{m \mu \beta r_{i}^{2}}
$$

or

$$
S=1.151\left(\frac{p_{\text {i.r }}-p_{\text {ext.b }}}{M} \frac{4 \pi R h}{q \mu}-\lg \frac{2.25 R T}{m \mu \beta r_{\mathrm{w}}^{2}}\right) .
$$


Due to the fact that a lot of parameters such as porosity and permeability of reservoir, fluid viscosity and compressibility are not known, then mean statistical values can be considered instead $\frac{m \mu \beta r_{\mathrm{w}}^{2}}{R}$. In most of the cases mentioned parameters are in ranges that are as follows: $R-$ from $10^{-3}$ to $0.2 \mathrm{mcm}^{2} ; m$ - from 0.1 to $0.3 ; \mu$ - from 0.05 to $50 \mathrm{mPa} \cdot \mathrm{s} ; \beta$ - from $10^{-3}$ to $10^{-1} 1 / \mathrm{MPa} ; r_{\mathrm{w}}-$ from 1.5 to $9.5 \mathrm{~cm}$.

Calculations show, that a combination of parameters changes from 0.0174 to $58.88 \mathrm{~min}^{-1}$. A value of logarithm changes from -1.76 to +1.77 . Mean value of logarithm can be considered as zero. Then following is obtained:

$$
S \approx 1.151\left(\frac{p_{\text {res }}-p_{\text {ext.b }}}{M}-\lg T\right) \pm 2,
$$

where $T$ is time, min; \pm 2 points out to possible deviations of thrue value of $S$ from calculated.

Ratio of potential production rate of $q_{\mathrm{p}}$ to real one $q_{\mathrm{a}}$ is determined from the ratio

$$
\frac{q_{\mathrm{p}}}{q_{\mathrm{a}}}=\frac{p_{\text {res }}-p_{\text {ext.b }}}{M} \frac{1}{\lg \frac{2.25 x t}{r_{\mathrm{w}}^{2}}} \approx \frac{p_{\text {res }}-p_{\text {ext.b }}}{M \lg T} .
$$

Actual productivity index is determined as a ratio of average production rate for test period to avarege pressure drawdown for the same period

$$
\eta_{\mathrm{a}}=q_{\mathrm{av}} / \Delta p_{\mathrm{av}},
$$

where a ratio of actial productivity index to potential one is

$$
\mathrm{RP}=\frac{\eta_{\mathrm{a}}}{\eta_{\mathrm{p}}}=\frac{p_{\text {res }}-p_{\text {ext.b }}-0.87 S M}{p_{\text {res }}-p_{\text {ext.b }}} .
$$

Estimation of potential reservoir capacity is deseribed below.

First, conditions for well flow are determined

$$
\Delta p=p_{\text {res }}-\gamma_{\mathrm{fl}} H>0,
$$

where $H$ is oil-bearing formation depth; $\gamma_{\mathrm{fl}}$ is specific gravity of fluid.

If the inequation is satisfied, then flow rate is found as

$$
q_{\mathrm{av}}=\eta_{\mathrm{a}}\left(p_{\mathrm{res}}-\gamma_{\mathrm{fl}} H\right)
$$

For an uncontaminated reservoir, potential flow rate can be calculated by the formula

$$
q_{\mathrm{a}(\mathrm{p})}=\eta_{\mathrm{a}} \frac{q_{\mathrm{P}}}{q_{\mathrm{a}}}\left(p_{\mathrm{res}}-\gamma_{\mathrm{fl}} H\right) .
$$

As a conclusion, some features of the interpretation of pressure diagram obtained during test of gas wells have to be noted. In this case, the basic calculation equation is

$$
p_{\mathrm{w}}^{2}=p_{\text {res }}^{2}-\frac{0.366 q_{r} \mu_{r} T_{\text {res }} z p_{0}}{R H T_{0}} \lg \frac{T+\theta}{\theta} .
$$

Plotting of pressure build-up curve in coordinates $p_{\mathrm{w}}^{2}, \lg \frac{T+\theta}{\theta}$ has to give a straight line that crosses vertical axis in a point, where $\lg \frac{T+\theta}{\theta}=0$, and as a result $p_{\mathrm{w}}=p_{\text {res. }}$.

It should be noted that plotting a graph with build-up of bottomhole pressure in second exponent and subsequent extraction of square root cause certain inconveniences using this technique and introduces errors into calculations.

Due to above mentioned, in order to process pressure build-up curves, obtained during test of gas wells, usual equation (2) is recommended. A formula (15) is derived to equation (2). If we consider

$$
\begin{aligned}
z \frac{T_{\text {res }}}{T_{0}} \frac{p_{0}}{p_{\text {av }}} & =\beta_{\mathrm{G}} ; q_{\mathrm{G}}=q_{\mathrm{G}(\text { (surf) }} \beta_{\mathrm{G}} \\
p_{\text {av }} & =\frac{p_{\text {res }}+p_{\text {ext.b }}}{2},
\end{aligned}
$$

and

then

$$
p_{\mathrm{w}}=p_{\text {res }}-0.183 q_{\mathrm{G}} \frac{\mu_{\mathrm{G}}}{R h} \lg \frac{T+\theta}{\theta} .
$$

\section{Application of results of modelling of pressure build-up curves in a well with use of packers}

Using above method of processing pressure buil-up curves, it is considered that liquid movement stops immediately after well is shut-in and production rate is zero, i.e. there is no afterflow.

Such case is hardly possible and its ignoring is caused by high mathematical challenges. That 
challengies arise when trying to take into account afterflow effect on pressure buil-up curves.

In many cases, if the test is performed in an openhole well and volume of sub- or interpacker space is very small, neglecting the afterflow effect is reasonable. It is also reasonable since the effect itself is almost imperceptible and the amount of information obtained using existing methods of interpretation is sufficient to make the right decision to choose an optimal completion option [6-8].

At the same time, quite often there are cases that cause the need to install a packer far from the bottome hole (100-150 m and more). It leads to the fact that volume of sub-packer space becomes a favorable base where afterflow effect appeare. An effect influences shape of build-up pressure curve. As a result, only a small section of pressure buil-up curve is used during processing.

Another factor that influences nature of pressure change during initial period of its buildup is an index of reservoir contamination. In the theory of pressure build-up, that was generalized by Ramey and Cobb in their work [9, 10], influence of resistance of fluid flow at bottome hole, associated with formation contamination is taken into account by introducing into calculation formulas a functions for an additional pressure drawdown which is proportional to a skin factor. In this case, nature of influence of depth and permeability of bottome hole zone is not considered. Instead, the presence of a contaminated bottomhole formation zone (BHFZ) is established. Influence of BHFZ is estimated by a generalized indicator of resistance that appears

$$
S \frac{\mu}{2 \pi R h} .
$$

This approach is acceptable when considering a reservoir system with a very deep drainage zone compared to a zone of formation contamination, dimensions of which are neglected.

However, a well test shows that contamination zone is commensurate with depth of the zone covered by formation study. Therefore, it is necessary to take into account non-stationary phenomena of pressure redistribution inside the zone of formation contamination during testing [9, 11-13].
Qualitative analysis of contamination zone does not give a reason weather it is connected to deep contamination of a formation itself or shallow with significant contamination in BHFZ.

Joint action of two considered effects significantly distorts pressure build-up curves. That makes it difficult to interpret and identify a certain finite rectilinear section. It is unclear how these factors influence separately and which one leads to curvature of the initial section of the pressure build-up curve.

Well test on exploration areas of fields is the most difficult to perform. As a consequence, packers are applied less and technical level of work decreases.

The Table shows change in some of test values depending on depth. The analysis showed that quality of work decreases with depth. First of all, a number of idle runs increases. The percentage of technically unsuccessful work at depths over 5 thousand meters was 8 times higher than that for depths less than 3 thousand meters. The number of tests with a certain obtained inflow significantly decreased.

Change in test values depending on depth

\begin{tabular}{|c|c|c|c|}
\hline $\begin{array}{c}\text { Depth of wells, } \\
\text { thousand } \mathrm{m}\end{array}$ & $\begin{array}{c}\text { Number } \\
\text { of operations per } \\
\text { one reservoir }\end{array}$ & Faults, \% & $\begin{array}{c}\text { Tests with } \\
\text { obtained } \\
\text { inflow, \% }\end{array}$ \\
\hline Less than 3 & 1.11 & 8.7 & 81 \\
\hline From 3 to 4 & 1.34 & 23.7 & 71 \\
\hline From 4 to 5 & 1.67 & 34.1 & 55.2 \\
\hline More than 5 & 3.00 & 65.3 & 33.3 \\
\hline
\end{tabular}

A detailed analysis of technically unsuccessful operations shown that packer leak does not change much with depth. Frequency of cases when a tool does not reach bottomhole do not change much with depth as well. At the same time, a number of failures of various parts of testing equipment, as well as percentage of technological defects, are sharply increasing with depth, which is often connected to each other.

The greatest challengies in tests were associated with closing of locking devices in order to record pressure recovery curves and with replacement of fluid in drill pipes after the end of the test. Two types of locking devices were used that are as follows: a shut-in rotary valve and a multi-cycle formation tester, which is closed by pulling the drill pipes. 
Both types of shut-in devices successfully operate at depths of down to $4000 \mathrm{~m}$. With increasing test depth, stability of shut-in devices decreases sharply. That is caused by increased flexibility of drill string, made up of pipes with diameters of 73,89 and $114 \mathrm{~mm}$, as well as with helical buckling of borehole, caused by the flexibility of drilling assemblies. Thus, weight indicator displays significant different values when a tool moves up and down. For example, at a depth of $5102 \mathrm{~m}$, weight indicator readings were as follows: 50 divisions moving downwqrds and 68 divisions moving upwards. An indicator of weight showed 45 divisions when a packer was set. Rotation of shut-in valve was only after a tool was pulled out to the readings of an indicator of 58 divisions. Shut-in valve was turned only after pulling a tool from 47 divisions (during packing) to 62 (during rotation). Next time, if necessary to turn shut-in valve it was lifted to indicator values equal to the average value of readings during the up and down run.

Under these conditions axial tension locking devices were even more unreliable due to the fact that pipes hang on the wall of borehole which lead to restraining force which brought to the effect similar to shock jars [10, 14-16].

Great challengies arose during efforts to activate hydraulic circulation valve. In case of oil or gas inflow from reservoir a valve could only be actuated in very rare cases. Valves of a mechanical type, triggered by dropping of a special rod that cuts a circulation plug were much more effective. They ensure communication of pipes with annular space. However, such valves can be installed in pipes with a diameter of $89 \mathrm{~mm}$ and higher.

The most promising are valves that are driven by rotation of drill pipes. They are either integrated in shut-off valve or installed just above it. When a lead screw of a shut-off valve is moved upwards, it pushes a special rod, which cuts a circulation plug. Unfortunately, such valves are not manufactured in series, but produced by well test team or drilling service companies.

However, there is no circulation guaranee even with use of described devices. During well test in Upper Cretaceous reservoirs at 5004-5040 m, $600 \mathrm{~m}$ of oil with gas were taken into 73-millimeter drill pipes.
To prevent release of degassed matter from the pipes, it was decided to fill pipes with water up to the top before and cut off a pin of circulation valve by pressure. Then circulation began at pressure on the top of $10 \mathrm{MPa}$. After washing was over, lifting started. Sudennly, during the lifting there was oveflow of a solution from the annular. A preventor was closed. Density of a solution was increased from 1240 to $1600 \mathrm{~kg} / \mathrm{m}^{3}$. Solution was pumped into the annular. Then a well was stopped for 12 hours. Only after that tool lifting was completed. Equipment inspection reveald that a circulation valve was not cut off, a rotational shut-off valve was not closed although it was turned more than it was needed. Circulation was carried out through a relief channel of a shutoff valve. As a result, shut-off valve was completely disabled.

During well test of foraminiferal deposits at a depth of 5151-5206 m, a similar case arose. There was a fault trying to cut a circulation valve at pressure of $35 \mathrm{MPa}$. A crowbar was launched into pipes to open a mechanical circulation valve, but it got stuck in pipes. The efforts to restore circulation continued for almost 2 days. Sharp drill string reciprocation led to the fact that a crowbar reached a valve and hit off the circulation plug.

In some cases, during well test of unconsolidated saturated with water sandstones liners were stucked by separated sand. Taking into account such sticks, liners in these areas are assembled from smooth and short drill pipes (114 $\mathrm{mm}$ in diameter and $10 \mathrm{~m}$ in length) and sometimes from a $108 \mathrm{~mm}$ diameter drill collar. In the upper part of a liner a left sub is instaled.

In case of stick a liner is detached from packers in a left sub, a well bore is worked out to a head of a liner and a liner is drilled around by a special bit made of butt-welding pipe of $146 \mathrm{~mm}$ in diameter with cut teeth reinforced by tungsten. Thereafter a trap made from the same tube is lowered and a liner is lifted.

In order to prevent a liner from spilling with sand, it is recommended, firstly, to carry out a test with installation of a fitting (preferably adjustable) to reduce depression to the formation. Secondly, an intake filter should be installed not in front of a formation but in the lowest part of a liner. Next time sand is washed out from the space below 
packer into pipes by an incoming fluid. If a well is shut-in (closed inlet or shut-off valve) sand settle in a much smaller amount (no more than $10 \%$ of volume of the space below a packer). This contributes to a more successful extraction of a liner.

However, washing fluid has to be considered as well. If a well is filled with a solution weighted with hematite, then upon contact with produced water, hematite may precipitate and block a filter. Therefore, it is recommended to inject light bentonite solution into test zone and above by 50-100 m.

There is an example following. By the time of a test, a well bottom hole was $5030 \mathrm{~m}$, bottomhole temperature was $180^{\circ} \mathrm{C}$, bottomhole pressure from a column of solution density of $1670 \mathrm{~kg} / \mathrm{m}^{3}$ was $81.5 \mathrm{MPa}$. The shoe of a column was at a depth of $4960 \mathrm{~m}$. Two packers with a diameter of $195 \mathrm{~mm}$ were installed in an intermediate column at depth of $4.936 \mathrm{~m}$, and the pressure drop was set at $30 \mathrm{MPa}$. Total duration of a two-cycle test was 173 minutes, including inflow of 50 minutes $(18 \pm 32)$ and build-up of 123 minutes $(57 \pm 66)$. For $50 \mathrm{~min}, 8.4 \mathrm{~m}^{3}$ of produced water was taken into pipes.

At the end of the test, it was found that a liner with packers were sticked. Equipment was reciprocation for 3.5 hours with hiting by jas. A drill string was disconnected with help of safety locker when a jar stoped working. Equipment was lifted to the surface. Processing of pressure diagrams made it possible to determine all the parameters of a formation that are as follows: initial pressure $53.8 \mathrm{MPa}$, permeability $220 \mu \mathrm{m}^{2}$, productivity index $-170 \frac{\mathrm{t}^{3} / \text { day }}{\mathrm{MPa}}$.

However, two packers and a liner of drill collar with a diameter of $146 \mathrm{~mm}$ and a length of $94 \mathrm{~m}$ remained in borehole. The packers were drilled around; part of the liner was recovered. Lower part of the liner was lost, so it was necessary to drill a new borehole. Since there was no sand in formation water the most likely reason of stick was considered as precipitation of hematite on the contact with formation water [17].

Challenges often occur when removing a packer from a place after the end of a test and appear to be as pulls of up to $200 \mathrm{kN}$. The main reason for this is that workers are in hurry. When tested, a packer is under influence of pressure drawdown and compressive forces that can reach tens of tons. As a result, rubber flows into gap between a packer support and walls of the well. If a packer is unset sharply then rubber is destroyed and acts as thrust packing ring. It is impossible to lift equipment in this case. Therefore it is needed to reciprocate equipment for several hours until the rubber is destroyed.

At the same time, such an issue can be avoided if a packer is removed from seat smoothly and slowly. For that it is needed to pull the equipment first until the weight indicator shows values that corresponds to equimpent run upwards before the packering. Wait for 2-3 minutes and increase pull by 2-3 divisions. Then again, wait for 2-3 minutes and, if necessary, and increase pull for another 2-3 divisions. In most cases a packer is removed from its place and extracted to the surface with minimal damage. If this procedure is applied then fluid flow to tubing and possible equipment weight increase have to be taken into account [18].

Results of analysis of experimental studies and actual pressure diagrams made it possible to understand a diversity of pressure build-up curves of four types, which are discussed below.

Fig. 1, a shows pressure buil-up curve, the points of which are plotted on a graph with a semilogarithmic scale. The curve represents a straight line (I type of pressure build-up curves). Such build-ups are obtained under "ideal" test conditions, i.e. when there is no contamination of the formation and afterflow effect.

However, it has been established practically that not all the build-up points plotted on a semilog plot are always placed on a straight line. It is much more common to have build-ups as it shown in Fig. $1, b-d$ (II, III and IV types of build-up curves).

II type PBUC (see Fig. 1, b) refers to the case when a formation is heavily contaminated. Herewith, start section of PBUC has a much greater slope than a final straight section. The curvature of PBUC increases with an afterflow effect.

The III type of PBUC (see Fig. 1, c) is characterized by concave to horizontal axis shape. They are encountered in the testing of a formation 
with an increased permeability in bottome hole zone, when slope of a start section of a PBUC is less than slope of a final one. It should be noted that such PBUCs are also encountered in cases when there is a steady pressure increase after well shut-in at weak inflow in the open test period. Herewith, PBUC does not have time to reach a final straight section during the time of pressure buil-up.
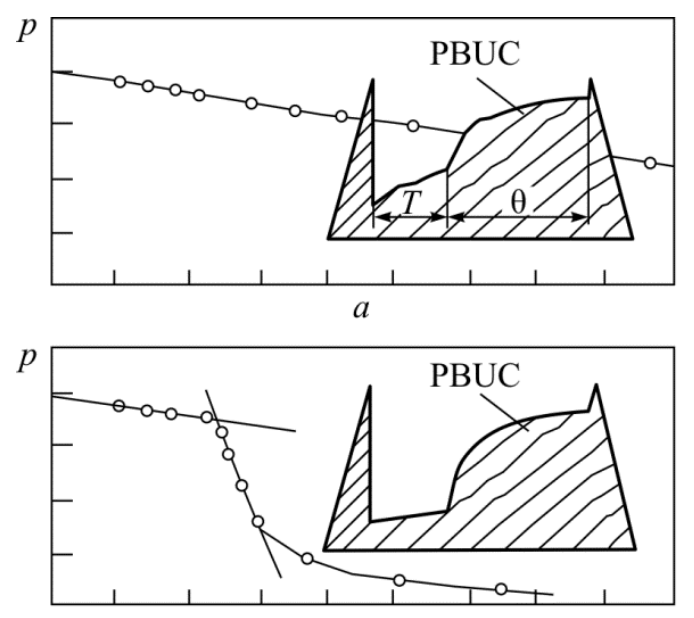

$b$
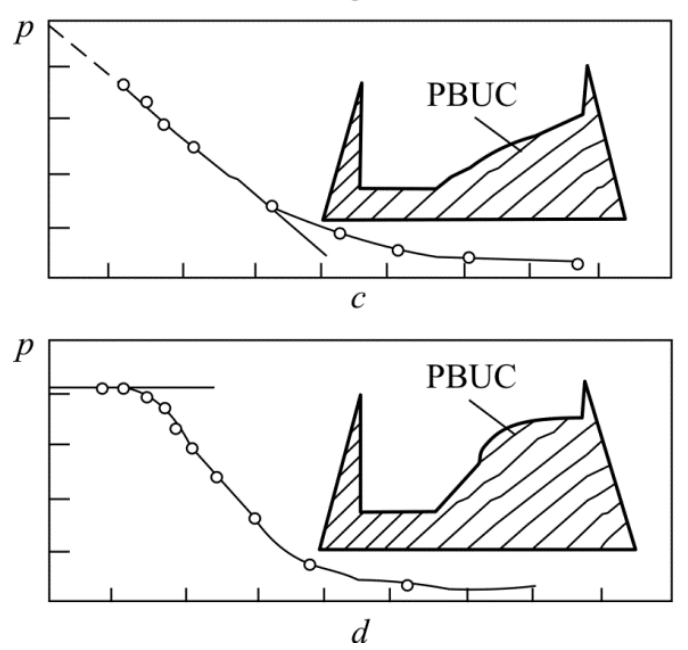

Fig. 1. Types of PBUCs at $\lg \frac{T+\theta}{\theta}$

Therefore, curves are not completely built-up. In such case, it is possible to determine only permeability of zone near well borehole. It is not always possible to judge unambiguously about permeability of distant part of a formation, as well as the magnitude of reservoir pressure.

The IV type of PBUC (see Fig. 1, $d$ ) includes curves, which are a special case of II type of PBUC, when permeability of distant part of a formation is much greater than permeability of bottomhole zone.
The slope of finite straight section of a PBUC in these cases equals almost zero. It can not be detected using recorded data of a deep gauge because of its limited sensitivity [19-20].
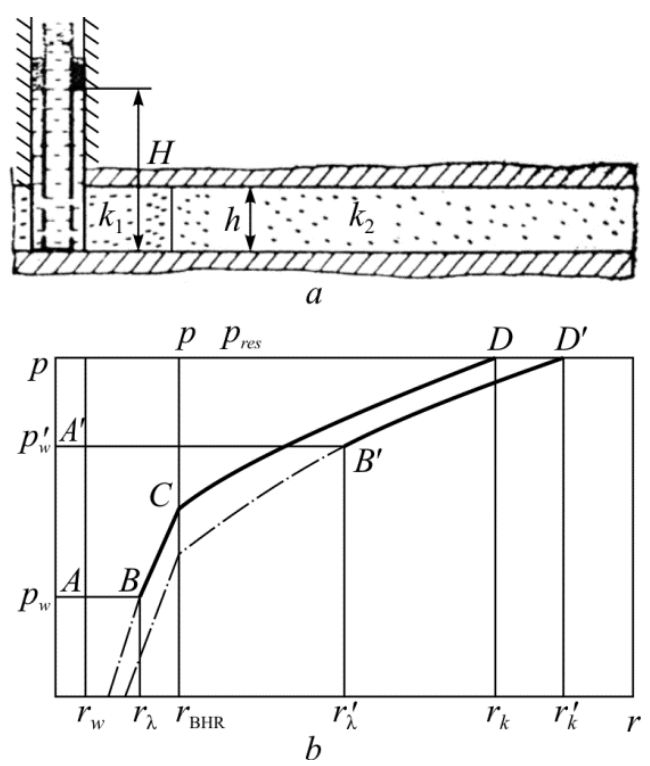

Fig. 2. A scheme of pressure distribution in a reservoir $A B C D$ and $A^{\prime} B^{\prime} D^{\prime}$ - pressure build-ups with the time of buil-up $\theta_{1}$ and $\theta_{2}\left(\theta_{1}<\theta_{2}\right): k_{1}$ - permeability around the bottom hole; $k_{2}$ - permeability around the radius; $h-$ liquid height in reservoir or bottome hole; $H$ - burial depth of oil-bearing formation; $p$ - pressure; $p_{w}^{\prime}-$ pressure during pressure build-up; $p_{w}$ - pressure above the filter; $r_{w}$ - well radius; $r_{\lambda}$ - radius of mean action; $r_{\mathrm{BHR}}$ - bottomhole radius; $r_{\lambda}^{\prime}$ - radius of initial pressure build-up; $r_{k}$ - approximation of schemes of pressure distribution; $r_{k}^{\prime}$ - curves of distribution of radius during pressure buil-up; $r$ - reservoir radius

\section{Conclusion}

Based on modeling of influence of mentioned factors on PBUC it was established that knowledge of a reason and nature of PBUC curvature will allow using all the information on pressure change after well shut-in during interpretation. Thus, it will help to determine characteristics of distant and bottomhole zones of the formation more accurately.

Interpretation of such PBUCs should consider that an area of influence of a well covered only borehole zone of a well with reduced permeability.

Implementation of packers while drilling of mentioned five wells allowed to overcome all geological problems successfully in short time and with great economic benefit. 


\section{References}

1. Suleimanov A.B. et al. Ekspluatatsiia morskikh neftegazovykh mestorozhdenii [Exploitation of offshore oil and gas fields]. Moscow, Nedra, 1986, 285 p.

2. Maksimov V.P. Ekspluatatsiia neftianykh mestorozhdenii v oslozhnennykh usloviiakh [Operation of oil fields in challenging conditions]. Moscow, Nedra, 1976, $239 \mathrm{p}$.

3. Avrushenko V.Kh. Rezinovye uplotniteli [Rubber seals]. Leningrad, Khimiia, 1978, 136 p.

4. Litvinov V.M. K voprosu o deformirovanii uplotnitel'nykh manzhet [On the issue of deformation of sealing cuffs]. Mashiny $i$ neftianoe oborudovanie, 1965, no. 5 , pp. $18-21$.

5. Varlamov P.S. Ispytanie plastov mnogotsiklovogo deistviia [Testing of multi-cycle action formation]. Moscow, Nedra, 1982, 247 p.

6. Kachanov L.M. Osnovy teorii plastichnosti [Fundamentals of plasticity theory]. Moscow, Nauka, $1969,420 \mathrm{p}$

7. Kvashnin G.P. Tekhnologiia vskrytiia i osvoeniia vodonosnykh plastov [Technology of perforation and development of aquifers]. Moscow, Nedra, 1987, 247 p.

8. Katalog kompanii Maritime Hydraulics [Catalog of Maritime Hydraulics Company], 1998-99.

9. Agarwal R.G., Al-Hussainy R., Ramey H.J. An investigation of wellbore storage and skin effekt in unsteady liguid flow. I. Analytical treatment. Society of Petroleum Engineers Journal, 1970, vol.10, iss.3, pp.279290. DOI: 10.2118/2466-PA

10. Ramey H.J. Short-time well test data interpretation in the presence of skin effect and wellbore storage. Journal of Petroleum Technology, 1970, vol.22, iss.01, pp.97-104. DOI: 10.2118/2336-PA

11. Composite catalog of oil field equipment and services. Texas, USA, World Oil A Gulf Publishing Company Publication, 1979-1981.
12. Mirzadzhanzade A.Kh., Ametov I.M, Khasaev A.M, Gusev V.N. Tekhnologiia i tekhnika dobychi nefti [Technology and techniques of oil production]. Moscow, Nedra, 1986, 382 p.

13. Asfandiiarov Kh.A., Maksutov R.A. Neftegazoproiavlenie i otkrytye fontany pri ekspluatatsii skvazhin [Oil and gas seepage and open fountains during well operation]. Moscow, Nedra, 1986, 232 p.

14. Kohlhaas C.A. A Method for analyzing pressures measured during drillstem-test flow periods. Journal of Petroleum Technology, 1972, vol.24, iss.10, pp.12781274. DOI: $10.2118 / 3695-P A$

15. Danko P.E., Popov A.G. Vysshaia matematika v uprazhneniiakh i zadachakh [Higher mathematics in exercises and tasks]. Moscow, Vysshaia shkola, 1974, $404 \mathrm{p}$.

16. Chernyi I.A. Neustanovivsheesia dvizhenie real'noi zhidkosti $\mathrm{v}$ trubakh [Unsteady flow of a real liquid in pipes]. Moscow, Nedra, 1975, 296 p.

17. Iasashin A.M. Vskrytie oprobovaniia i ispytaniia skvazhin [Perforation and well testing]. Moscow, Nedra, 1979, 264 p.

18. Dzhanakhmedov A.Kh., Mamedov V.T., Gurbanov S.R. Raschet i proektirovanie pakernykh ustroistv [Calculation and design of packer devices]. Baku, Elm, 1998, 86 p.

19. Oborudovanie dlia ekspluatatsii neftianykh i gazovykh skvazhin s ustroistvami dlia preduprezhdeniia otkrytykh fontanov [Equipment for operation of oil and gas wells with devices for preventing open fountains]. Katalog Tsentral'nogo instituta nauchno-tekhnicheskoi informatsii i tekhniko-ekonomicheskikh issledovanii po khimicheskomu i neftianomu mashinostroeniiu. Moscow, 1989, 112 p.

20. Gaivoronskii A.A., Tsybin A.A. Kreplenie skvazhin i razobshchenie plastov [Well cementing and formation separation]. Moscow, Nedra, 1981, 387 p.

\section{Библиографический список}

1. Эксплуатация морских нефтегазовых месторождений / А.Б. Сулейманов [и др.]. - М.: Недра, 1986. -285 c.

2. Максимов В.П. Эксплуатация нефтяных месторождений в осложненных условиях. - М.: Недра, 1 976. -239 c.

3. Аврушенко В.Х. Резиновые уплотнители. - Л.: Химия, 1978. - $136 \mathrm{c.}$

4. Литвинов В.М. К вопросу о деформировании уплотнительных манжет // Машины и нефтяное оборудование / РНТС ВНИИОЭНГ. - М., 1965. № 5. - C. 18-21.

5. Варламов П.С. Испытание пластов многоциклового действия. - М.: Недра, 1982. - 247 с.

6. Качанов Л.М. Основы теории пластичности. М.: Наука, 1969. - 420 с.
7. Квашнин Г.П. Технология вскрытия и освоения водоносных пластов. - М.: Недра, 1987. - 247 с.

8. Каталог компаний Maritime Hydraulics / The University of Alaska Fairbanks, 1998-1999.

9. Agarwal R.G., Al-Hussainy R., Ramey H.J. An investigation of wellbore storage and skin effekt in unsteady liguid flow. I. Analytical Treatment // Society of Petroleum Engineers Journal. - 1970. - Vol. 10, iss. 3. P. 279-290. DOI: 10.2118/2466-PA

10. Ramey H.J. Short-time well test data interpretation in the presence of skin effect and wellbore storage // Journal of Petroleum Technology. - 1970. Vol. 22, iss. 01. - P. 97-104. DOI: 10.2118/2336-PA

11. Composite catalog of oil field equipment and services / World Oil A Gulf Publishing Company Publication. - Texas, USA, 1979-1981. 
12. Технология и техника добычи нефти: учеб. для вузов / А.Х. Мирзаджанзаде, И.М. Аметов, А.М. Хасаев, В.Н. Гусев. - М.: Недра, 1986. - 382 с.

13. Асфандияров Х.А., Максутов Р.А. Нефтегазопроявление и открытые фонтаны при эксплуатации скважин. - М.: Недра, 1986. - 232 с.

14. Kohlhaas C.A. A method for analyzing pressures measured during drillstem-test flow periods // Journal of Petroleum Technology. - 1972. - Vol. 24, iss. 10. P. 1278-1274. DOI: 10.2118/3695-PA

15. Данко П.Е., Попов А.Г. Высшая математика в упражнениях и задачах: учеб. пособие для втузов. М.: Высшая школа, 1974. - 404 с.
16. Черный И.А. Неустановившееся движение реальной жидкости в трубах. - М.: Недра, 1975. - 296 с.

17. Ясашин А.М. Вскрытие опробования и испытания скважин. - М.: Недра,1979. - 264 с.

18. Джанахмедов А.Х., Мамедов В.Т., Гурбанов С.Р. Расчет и проектирование пакерных устройств. Баку: Элм, 1998. - 86 с.

19. Оборудование для эксплуатации нефтяных и газовых скважин с устройствами для предупреждения открытых фонтанов. Каталог ЦИНТИХИМНЕФТЕМаш. M., 1989. - 112 c.

20. Гайворонский А.А., Цыбин А.А. Крепление скважин и разобщение пластов. - М.: Недра, 1981. - 387 с.

Please cite this article in English as:

Mikailova N.E. Simulation of well test processes with application of packers. Bulletin of PNRPU. Geology. Oil \& Gas Engineering \& Mining, 2017, vol.16, no.1, pp.40-48. DOI: 10.15593/2224-9923/2017.1.5

Просьба ссылаться на эту статью в русскоязычных источниках следующим образом:

Микаилова Н.Э. Моделирование процессов испытания скважин при применении пакеров // Вестник Пермского национального исследовательского политехнического университета. Геология. Нефтегазовое и горное дело. - 2017. - Т.16, №1. - С.40-48. DOI: $10.15593 / 2224-9923 / 2017.1 .5$ 